\title{
Hubungan Obesitas dengan Kejadian Hipertensi Derajat 1 di Pos Pembinaan Terpadu Penyakit Tidak Menular (Posbindu PTM) Kantor Kesehatan Pelabuhan Bandung Tahun 2016
}

\author{
The Relationship of Obesity with Incidence of Hypertension Stage 1 at \\ Integrated Coaching Post of Non-Communicable Disease (Posbindu PTM) \\ Port Health Office of Bandung in 2016
}

\author{
Teguh Dhika Rohkuswara ${ }^{a^{*}}$, Syahrizal Syarifb \\ aDitjen P2P Kemenkes RI, Kantor Kesehatan Pelabuhan (KKP) Bandung, Indonesia \\ bDepartemen Epidemiologi, Fakultas Kesehatan Masyarakat, Universitas Indonesia
}

\section{A B S T R A K}

Hipertensi sampai saat ini masih menjadi masalah kesehatan di dunia termasuk Indonesia. Prevalensi hipertensi di Indonesia, cukup tinggi yaitu sebesar 25,8\% (Riskesdas, 2013). Sebagian besar penderita hipertensi termasuk dalam kelompok hipertensi derajat 1 dan separuhnya tidak menyadari sebagai penderita. Hipertensi bukan penyakit kausal tunggal, ada berbagai faktor yang berkontribusi terhadap munculnya hipertensi, salah satunya yang sering ditemukan adalah obesitas. Penelitian ini bertujuan untuk mengetahui besarnya hubungan antara obesitas dengan kejadian hipertensi derajat 1 di Posbindu PTM Kantor Kesehatan Pelabuhan Bandung. Desain penelitian adalah cross sectional, menggunakan data sekunder kegiatan Posbindu PTM KKP Bandung tahun 2016. Subjek penelitian adalah pegawai instansi Pemerintah dan BUMN di lingkungan Bandara Husein Sastranegara Bandung dan Pelabuhan Cirebon yang melakukan pemeriksaan kesehatan di Posbindu PTM KKP Bandung pada tahun 2016 yaitu sebanyak 206 orang. Hasil penelitian menunjukan bahwa proporsi hipertensi derajat 1 di Posbindu PTM KKP Bandung tahun 2016 yaitu sebesar 41,7\% dan obesitas sebesar $54,9 \%$. Berdasarkan analisis cox regresi, responden yang obesitas (IMT e"25) memiliki risiko sebesar 1,681 kali untuk menderita hipertensi derajat 1 dibandingkan yang tidak obesitas setelah dik ontrol variabel umur, riwayat hipertensi keluarga dan aktivitas fisik. Pengoptimalan Posbindu PTM meningkatkan peran serta masyarakat dan mengaplikasikan perilaku GERMAS diharapkan dapat mengendalikan obesitas dan hipertensi. Kata kunci: Hipertensi derajat 1, Obesitas, Posbindu PTM

\section{Pendahuluan}

Global Status Report (GSR) on non-communicable diseases 2010, World Health Organization (WHO) menunjukan Penyakit Tidak Menular (PTM) merupakan penyebab kematian terbesar di seluruh dunia. Hipertensi merupakan Penyebab kematian terbesar dari kelompok penyakit kardiovaskuler yaitu sebesar 13\%. Menurut WHO dan The International Society of Hipertension (ISH) tahun 2003, terdapat 600 juta penderita hipertensi di seluruh dunia dan 3 juta diantaranya meninggal setiap tahunnya. ${ }^{1}$ Di Indonesia, prevalensi hipertensi cukup tinggi. Prevalensi hipertensi menurut Riskesdas Tahun 2013 di Indonesia yang didapat melalui pengukuran pada umur $\geq 18$ tahun yaitu sebesar 25,8\%. Terdapat 7 (tujuh) Provinsi yang melebihi angka nasional, diantaranya yaitu Provinsi Jawa Barat. Prevalensi hipertensi di Provinsi Jawa Barat yaitu sebesar 29,4\%.2

Hipertensi terdiri dari 2 (dua) derajat yaitu hipertensi derajat 1 (sistolik 140-159 mmHg dan atau
A B S TR A C T

Hypertension is still a health problem in the world including Indonesia. The prevalence of hypertension in Indonesia is quite high at $25.8 \%$ (Riskesdas, 2013). Most people with hypertension are included in the 1st stage hypertension group and half were unaware as a sufferer. Hypertension is not a single causal disease, there are various factors that contribute to the emergence of hypertension, one of which is often found is obesity. This study aims to determine the magnitude of the relationship between obesity with incidence of hypertension stage 1 in Posbindu PTM Port Health Office (PHO) of Bandung. The research design is cross sectional, using secondary data of Posbindu PTM PHO of Bandung, activities in 2016. The Research subjects are employees of Government agencies and state-owned enterprises in the Husein Sastranegara Bandung Airport and Cirebon Port which conducted health checks at Posbindu PTM PHO of Bandung in 2016, which were 206 people. The results showed that the proportion of stage 1 hypertension in Posbindu PTM PHO of Bandung in 2016, that is $41.7 \%$ and obesity of $54.9 \%$. People with obesity (BMI $\geq 25$ ) had a risk of 1,681 times for hypertension stage 1 compared to non-obese individuals after controlling for age variables, family history of hypertension and physical activity. Optimization of Posbindu PTM, increasing public participation and applying GERMAS behavior is expected to control obesity and hypertension.

Keyword: Hypertension stage 1, Obesity, Posbindu PTM diastolik 90-99 $\mathrm{mmHg}$ ) dan derajat 2 (sistolik $\geq 160$ dan atau diastolik $\geq 100$ ). Sebagian besar penderita hipertensi termasuk dalam kelompok hipertensi derajat I. Terdapat $50 \%$ penderita tidak menyadari sebagai penderita, sehingga penyakitnya lebih berat karena tidak merubah dan menghindari faktor risiko. ${ }^{3}$

Faktor risiko hipertensi dapat dibedakan menjadi 2 (dua) faktor yaitu faktor yang tidak dapat diubah berupa ras, umur, jenis kelamin, dan keturunan (riwayat hipertensi keluarga). Faktor yang dapat diubah seperti kegemukan (obesitas), stress, merokok, kurang olahraga, konsumsi alkohol berlebih, konsumsi garam berlebih dan hiperlipidemia. ${ }^{4}$ Salah satu faktor risiko hipertensi yang dapat diubah dan sering ditemukan adalah obesitas.

Obesitas saat ini menjadi masalah kesehatan dunia. Data yang dikumpulkan dari seluruh dunia

*Korespondensi: Ditjen P2P Kemenkes RI, Kantor Kesehatan Pelabuhan (KKP) Bandung, Jl. Cikapayang No 5 Bandung 40116, Indonesia; Email: rteguhdhika@yahoo.com; Phone: +62 22 419305; HP: +62852 27725009 
memperlihatkan adanya peningkatan prevalensi overweight dan obesitas pada 10-15 tahun terakhir. Di Indonesia, angka obesitas terus meningkat, pada laki-laki dewasa terjadi peningkatan dari 13,9\% pada tahun 2007 menjadi 19,7\% pada tahun 2013. Sedangkan pada wanita dewasa terjadi kenaikan yang sangat ekstrim mencapai 18,1\%. Dari 14,8\% pada tahun 2007 menjadi 32,9\% pada tahun 2013. ${ }^{2}$

Menurut beberapa penelitian, obesitas memiliki hubungan yang bermakna dengan kejadian hipertensi. Berdasarkan Studi Framingham menyebutkan bahwa kelebihan berat badan (kelebihan berat badan dan obesitas), menyumbang sekitar 26\% kasus hipertensi pada pria dan $28 \%$ pada wanita. ${ }^{5}$ Dan penelitian Jullaman menyebutkan bahwa orang yang memiliki IMT tergolong obesitas memiliki risiko sebesar 1,64 kali untuk menderita hipertensi derajat 1 dibandingkan yang tergolong IMT normal. ${ }^{6}$ Serta Penelitian Sari yang menyebutkan bahwa orang dengan obesitas sentral memiliki risiko sebesar 1,6 kali untuk menderita hipertensi derajat 1 dibandingkan dengan yang tidak obesitas sentral.?

Kantor Kesehatan Pelabuhan Bandung (KKP) Bandung adalah Unit Pelaksana Teknis (UPT) Kementerian Kesehatan dibawah Direktorat Jenderal Pencegahan dan Pengendalian Penyakit (P2P), yang memiliki wilayah kerja pelabuhan dan bandara di Provinsi Jawa Barat. KKP Bandung memiliki fungsi diantaranya Pengendalian Penyakit Tidak Menular (PTM) melalui kegiatan skrining PTM pada tahun 2015 dan Pos Pembinaan Terpadu (Posbindu) PTM pada tahun 2016. Berdasarkan hasil kegiatan skrining PTM tahun 2015 pada pegawai instansi Pemerintah dan BUMN di wilayah kerja KKP Bandung, hipertensi merupakan penyakit terbanyak yang ditemukan (15\%) dan sebagaian besar pegawai memiliki berat badan lebih termasuk overweight dan obesitas (38\%). ${ }^{8}$ Akan tetapi belum ada gambaran yang jelas mengenai hipertensi dan bagaimana pengaruh faktor risiko salah satunya obesitas dengan kejadian hipertensi khususnya hipertensi derajat 1 di wilayah kerja KKP Bandung tersebut. Berdasarkan hal di atas, peneliti tertarik untuk mengetahui gambaran mengenai kejadian hipertensi derajat 1 dan obesitas serta untuk mengetahui besarnya hubungan obesitas dengan kejadian hipertensi derajat 1 di Posbindu PTM KKP Bandung.

\section{Metode Penelitian}

Penelitian ini menggunakan data sekunder yang diambil dari kegiatan Posbindu PTM di wilayah kerja KKP Bandung yaitu wilayah kerja Bandar Udara Husein Sastranegara Bandung dan Pelabuhan Cirebon. Studi ini menggunakan pendekatan cross sectional yang merupakan rancang penelitian dengan melakukan pengukuran atau pengamatan pada saat bersamaan atau melakukan pemeriksaan status paparan dan status penyakit pada titik yang bersamaan. ${ }^{9}$

Populasi yang diamati dalam penelitian ini adalah pegawai instansi Pemerintah dan BUMN di lingkungan Bandar Udara Husein Sastranegara Bandung dan
Pelabuhan Cirebon berusia 20-50 tahun yang melakukan pemeriksaan kesehatan di Posbindu PTM KKP Bandung pada tahun 2016 dan bisa dilakukan analisis yaitu sebanyak 206 orang. Dan terdapat 34 responden yang tidak bisa dianalisis lebih lanjut (30 orang karena datanya tidak lengkap, 2 orang pernah didiagnosis hipertensi sebelumnya dan 2 orang hasil pemeriksaan tekanan darah tergolong hipertensi derajat 2). Penghitungan besar sampel dalam penelitian ini, menggunakan rumus data populasi untuk uji hipotesis. ${ }^{9}$ Berdasarkan hasil perhitungan tersebut, diketahui besar sampel yang terbesar sebanyak 162 responden. Pengambilan sampel dengan cara total populasi karena memenuhi syarat minimal sampel. Jadi besar sampel yang digunakan yaitu sebanyak 206 responden.

Variabel yang akan diteliti adalah kejadian hipertensi derajat 1 (dependen) dan obesitas (independen), selain itu diteliti pula variabel yang lain (kovariat) meliputi variabel umur, jenis kelamin, hipertensi keluarga, kebiasaan merokok, kebiasaan konsumsi buah dan sayuran, konsumsi alkohol, aktivitas fisik dan kadar gula darah sewaktu (GDS). Pengukuran variabel penelitian tersebut berdasarkan pedoman pengukuran faktor risiko Posbindu PTM Kemenkes RI Tahun 2015.10

Analisis yang digunakan adalah analisis cox regression. Lee \& Chia merekomendasikan penggunaan model risiko proporsional cox untuk menghitung Prevalen Rasio (PR) pada studi cross sectional. ${ }^{11}$ Penelitian ini menggunakan ukuran asosiasi PR karena kejadian hipertensi derajat 1 merupakan kejadian yang sering (prevalensi $>10 \%$ ).

Penelitian ini dilaksanakan atas dasar persetujuan dari Komite Etik Fakultas Kesehatan Masyarakat Universitas Indonesia. Data yang diambil sudah atas izin dari Kepala Kantor Kesehatan Pelabuhan (KKP) Bandung dan Kepala Seksi Upaya Kesehatan dan Lintas Wilayah (UKLW) selaku penanggungjawab kegiatan Posbindu PTM. Semua data yang dikumpulkan dalam penelitian ini hanya digunakan untuk keperluan ilmiah. Kode dan identitas subjek penelitian, sangat dirahasiakan untuk umum.

\section{Hasil}

Proporsi Kejadian Hipertensi Derajat 1 dan Obesitas

Dari 206 responden didapatkan proporsi hipertensi derajat 1 di Posbindu PTM KKP Bandung Tahun 2016 yaitu sebesar 41,7\%. Sedangkan proporsi obesitas sebesar 54,9\% (tabel 1).

Proporsi Kejadian Hipertensi Derajat 1 menurut Variabel Penelitian

Berdasarkan variabel obesitas, proporsi kejadian hipertensi pada responden yang obesitas sebesar 54\% atau 2 kali dari responden yang tidak obesitas (tabel 2). Sedangkan berdasarkan variabel kovariat lainnya menunjukan terdapat perbedaan diantaranya variabel umur, riwayat hipertensi keluarga, konsumsi buah dan sayuran dan aktivitas fisik (tabel 3). 
Rohkuswara \& Syarif, Hubungan Obesitas dengan Kejadian Hipertensi di Posbindu PTM KKP Bandung

Tabel 1. Distribusi Frekuensi Kejadian Hipertensi Derajat 1 dan Obesitas di Posbindu PTM KKM Bandung

\begin{tabular}{llrr}
\multicolumn{1}{c}{ Variabel } & \multicolumn{1}{c}{ Kategori } & $\begin{array}{c}\text { Jum lah } \\
(n=206 \text { orang })\end{array}$ & Persentase (\%) \\
\hline Kejadian Hipertensi & Normotensi & 120 & 58,3 \\
Derajat 1 & Hipertensi Derajat 1 & 86 & 41,7 \\
\hline Obesitas & Tidak Obesitas & 93 & 45,1 \\
& Obesitas & 113 & 54,9 \\
\hline
\end{tabular}

Tabel 2. Proporsi Kejadian Hipertensi Derajat 1 menurut Variabel Obesitas di Posbindu PTM KKP Bandung

\begin{tabular}{lcrrr}
\hline \multirow{2}{*}{ Variabel } & \multicolumn{2}{c}{ Hipertensi Derajat 1 } & Jum lah \\
\cline { 3 - 4 } & Obesitas & $\begin{array}{l}\text { Hipertensi } \\
\text { Derajat 1 }\end{array}$ & Normotensi & 113 $(100 \%)$ \\
\hline Obesitas & $61(54,0 \%)$ & $52(46,0 \%)$ & $93(100 \%)$ \\
\hline
\end{tabular}

Proporsi hipertensi derajat 1 meningkat seiring peningkatan umur. Proporsi terbesar pada kelompok umur 41-50 tahun yaitu sebesar 50. 4\% atau lebih dari 5 kali dibandingkan kelompok umur 20-30 tahun. Sebagian besar responden (68,5\%) yang ada riwayat hipertensi keluarga menderita hipertensi derajat 1 atau 2 kali lebih besar dibanding yang tidak ada riwayat.
Sebagian besar responden yang konsumsi buah dan sayurannya kurang, menderita hipertensi derajat 1 $(50,6 \%)$ atau 1,3 kali lebih besar dibandingkan konsumsi buahnya cukup. Pada responden yang aktivitas fisiknya kurang, proporsi kejadian hipertensi derajat 1 yaitu sebesar 64,7\% atau hampir 2 kali lebih besar dibandingkan aktivitas fisiknya cukup (tabel 3).

Tabel 3. Proporsi Kejadian Hipertensi Derajat 1 menurut Variabel Kovariat Lainnya di Posbindu PTM KKP Bandung

\begin{tabular}{|c|c|c|c|c|}
\hline \multirow[b]{2}{*}{ Variabel } & & \multicolumn{2}{|c|}{ Hipertensi Derajat 1} & \multirow[b]{2}{*}{ Jumlah } \\
\hline & & $\begin{array}{l}\text { Hipertensi } \\
\text { Derajat } 1\end{array}$ & Normotensi & \\
\hline \multirow[t]{3}{*}{ Umur } & 41-50 tahun & $67(50,4 \%)$ & $66(49,6 \%)$ & $133(100 \%)$ \\
\hline & $31-40$ tahun & $17(33,3 \%)$ & $34(66,7 \%)$ & $51(100 \%)$ \\
\hline & 20-30 tahun & $2(9,1 \%)$ & $20(90,9 \%)$ & $22(100 \%)$ \\
\hline \multirow[t]{2}{*}{ Jenis Kelamin } & Laki laki & $66(43,1 \%)$ & $87(56,9 \%)$ & $153(100 \%)$ \\
\hline & Perempuan & $20(37,7 \%)$ & $33(62,3 \%)$ & $53(100 \%)$ \\
\hline Hipertensi & Ada & $37(68,5 \%)$ & $17(31,5 \%)$ & $54(100 \%)$ \\
\hline Keluarga & Tidak ada & $49(32,2 \%)$ & $103(67,8 \%)$ & $152(100 \%)$ \\
\hline \multirow[t]{2}{*}{ Kebiasaan Merokok } & Merokok & $31(38,3 \%)$ & $50(61,7 \%)$ & $81(100 \%)$ \\
\hline & Tidak & $55(44,0 \%)$ & $70(56,0 \%)$ & $125(100 \%)$ \\
\hline Konsumsi buah dan & Kurang & $40(50,6 \%)$ & $39(49,4 \%)$ & $79(100 \%)$ \\
\hline sayuran & Cukup & $46(36,2 \%)$ & $81(63,8 \%)$ & $127(100 \%)$ \\
\hline \multirow[t]{2}{*}{ Konsumsi Alkohol } & $\mathrm{Ya}$ & $3(37,5 \%)$ & $5(62,5 \%)$ & $8(100 \%)$ \\
\hline & Tidak & $83(41,9 \%)$ & $115(58,1 \%)$ & $198(100 \%)$ \\
\hline \multirow[t]{2}{*}{ A ktivitas Fisik } & Kurang & $44(64,7 \%)$ & $24(35,3 \%)$ & $68(100 \%)$ \\
\hline & Cukup & $42(30,4 \%)$ & $96(69,6 \%)$ & $138(100 \%)$ \\
\hline \multirow[t]{2}{*}{ KadarGDS } & Tidak & $4(50,0 \%)$ & $4(50,0 \%)$ & $8(100 \%)$ \\
\hline & Normal & $82(41,4 \%)$ & $116(58,6 \%)$ & $198(100 \%)$ \\
\hline
\end{tabular}

Tabel 4. Full Model Analisis Multivariat Hubungan Obesitas dengan Kejadian Hipertensi Derajat 1

\begin{tabular}{|c|c|c|c|c|c|c|}
\hline \multirow{2}{*}{ Variabel } & \multirow{2}{*}{ B } & \multirow{2}{*}{ SE } & \multirow{2}{*}{ PR } & \multicolumn{2}{|c|}{ C I $95 \%$} & \multirow{2}{*}{$p$ value } \\
\hline & & & & Lower & Upper & \\
\hline Obesitas & 0,523 & 0,245 & 1,687 & 1,043 & 2,730 & 0,033 \\
\hline $\begin{array}{l}\text { Jen is Kelam in } \\
\mathrm{Um} \mathrm{ur}\end{array}$ & $-0,103$ & 0,280 & 0,903 & 0,521 & 1,563 & 0,714 \\
\hline $31-40$ tahun & 0,895 & 0,765 & 2,447 & 0,547 & 10,953 & 0,242 \\
\hline $41-50$ tahun & 1,215 & 0,732 & 3,372 & 0,804 & 14,145 & 0,097 \\
\hline Riwayat Hipertensi & 0,568 & 0,229 & 1,765 & 1,127 & 2,762 & 0,014 \\
\hline Kebiasaan M erokok & $-0,066$ & 0,246 & 0,936 & 0,578 & 1,516 & 0,789 \\
\hline $\begin{array}{l}\text { Konsumsi Buah dan } \\
\text { Sayuran }\end{array}$ & 0,172 & 0,224 & 1,187 & 0,765 & 1,841 & 0,444 \\
\hline Konsumsi Alkohol & $-0,497$ & 0,618 & 0,609 & 0,181 & 2,043 & 0,422 \\
\hline A ktifitas Fisik & 0,531 & 0,232 & 1,701 & 1,080 & 2,678 & 0,022 \\
\hline Kadar GDS & $-0,003$ & 0,524 & 0,997 & 0,357 & 2,781 & 0,995 \\
\hline
\end{tabular}


Hubungan Obesitas dengan Kejadian Hipertensi Derajat 1

Berdasarkan hasil analisis bivariat diketahui bahwa obesitas berhubungan secara bermakna dengan dengan kejadian hipertensi derajat 1. Dari uji statistik diperoleh nilai PR sebesar 2,008 (CI 95\%: 1,379-2,925), artinya responden dengan obesitas memiliki risiko 2,008 kali untuk menderita hipertensi derajat 1 dibandingkan responden yang tidak obesitas (tabel 5).

Setelah dilakukan analisis multivariat, terdapat 3 variabel kovariat yang diindentifikasi sebagai confounding yaitu variabel umur, riwayat hipertensi keluarga dan aktivitas fisik. Sehingga didapatkan nilai PR adjusted $_{\text {antara }}$ hubungan obesitas dengan kejadian hipertensi derajat I yaitu sebesar 1,681 kali (CI 95\%: 1,049-2,696), artinya responden dengan obesitas memiliki risiko sebesar 1,681 kali untuk menderita hipertensi derajat 1 dibandingkan yang tidak obesitas setelah dikontrol variabel umur, riwayat hipertensi keluarga dan aktivitas fisik (tabel 5).

Tabel 5. Hubungan Obesitas dengan Kejadian Hipertensi Derajat 1 di Posbindu PTM KKP Bandung

\begin{tabular}{lrrrr} 
& \multicolumn{1}{c}{ Variabel } & $\begin{array}{c}\text { Crude PR } \\
(95 \% \mathrm{CI})\end{array}$ & $\begin{array}{c}\text { Adjusted PR* } \\
(95 \% \mathrm{CI})\end{array}$ & P value* \\
\hline Obesitas & Obesitas & 2,008 & 1,681 & \\
& Tidak Obesitas & $(1,379-2,925)$ & $(1,049-2,696)$ & 0,031 \\
\hline
\end{tabular}

*Setelah dikontrol dengan variabel umur, riwayat hipertensi keluarga dan aktivitas fisik

\section{Diskusi}

Penelitian ini merupakan analisis data sekunder, tidak semua variabel kovariat diteliti, walaupun sudah dilakukan pengontrolan dengan menggunakan analisis multivariat, kemungkinan masih kurang dapat menjelaskan secara menyeluruh tentang faktor risiko lain yang terkait dengan hubungan obesitas dengan kejadian hipertensi derajat 1.

Berdasarkan penelitian sebelumnya, menyebutkan adanya hubungan yang bermakna antara obesitas dengan kejadian hipertensi derajat 1.6,7 Hubungan obesitas telah lama diketahui dan telah banyak dilaporkan oleh banyak peneliti, namun mekanisme terjadinya hipertensi akibat obesitas hingga saat ini belum jelas. Sebagian besar peniliti menitikberatkan patofisiologis tersebut pada tiga hal utama yaitu gangguan sistem autonom, resitensi insulin serta abnormalitas struktur dan fungsi pembuluh darah. Ketiga hal tersebut dapat saling mempengaruhi satu dengan yang lainnya. ${ }^{12}$

Pada obesitas, tahanan perifer berkurang sedangkan saraf simpatis meninggi dengan aktifitas renin plasma yang rendah. Makin besar massa tubuh, makin banyak darah yang dibutuhkan untuk memasok oksigen dan makanan ke jaringan tubuh. Kondisi obesitas berhubungan dengan peningkatan volume intravaskuler dan curah jantung. Daya pompa jantung dan sirkulasi volume darah penderita hipertensi lebih tinggi dibandingkan dengan penderita hipertensi dengan berat badan normal. ${ }^{13}$ penurunan berat badan merupakan unsur yang paling berperan dalam pencegahan dan pengobatan hipertensi. Pasien hipertensi didiorong untuk melakukan penurunan berat badan bila mengalami obesitas dan hal ini akan berefek pada penurunan tekanan darah. ${ }^{14}$

Setiap $1 \mathrm{~kg}$ peningkatan berat badan memiliki HR untuk menderita hipertensi sebesar 1,36 (CI 95\%: 1,29-1,45). ${ }^{15}$ Selain itu berdasarkan hasil penelitian sebelumnya menunjukan bahwa setiap kilogram penurunan berat badan dapat menurunkan tekanan darah sistolik sebanyak 1,05 $\mathrm{mmHG}$ dan diastolik sebanyak 0,92 mmHg. ${ }^{16}$

Pada penelitian ini didapatkan proporsi kejadian hipertensi derajat 1 di Posbindu PTM KKP Bandung tahun 2016 sebesar 41,7\% atau 86 orang dari 206 responden. Hasil penelitian ini lebih tinggi apabila dibandingkan dengan angka Nasional dan Provinsi Jawa Barat menurut Riskesdas Tahun 2013. ${ }^{2}$ Perbedaan tersebut terjadi karena meskipun sudah dilakukan eksklusi terhadap responden yang memiliki riwayat hipertensi atau dalam pengobatan hipertensi, kemungkinan masih adanya responden yang sebenarnya sudah menderita hipertensi tetapi tidak pernah melakukan pemeriksaan kesehatan, seperti diketahui sebelumnya bahwa 50\% penderita hipertensi tidak menyadari bahwa mereka menderita hipertensi.

Berdasarkan hasil penelitian didapatkan juga proporsi obesitas di Posbindu PTM KKP Bandung tahun 2016 sebesar 54,9\% atau lebih tinggi dibandingkan menurut penelitian Jullaman dan Riskesdas tahun 2013.2,6 Perbedaan tersebut disebabkan karena perbedaan penggunaan kriteria obesitas. Pada penelitian ini mengunakan cut of point untuk kategori obesitas yaitu IMT $\geq 25$ (kriteria WHO) sedangkan pada penelitian lainnya, menggunakan IMT $\geq 27$ (Kriteria Kemenkes). Sehingga otomatis proporsi obesitas pada penelitian ini lebih tinggi.

Hasil penelitian ini juga menunjukan bahwa obesitas memiliki hubungan yang bermakna dengan kejadian hipertensi derajat 1 di Posbindu PTM KKP Bandung tahun 2016. Hasil analisis bivariat menunjukan bahwa responden yang memiliki berat badan obesitas (IMT e"25) berisiko 2,008 kali (CI 95\%: 1,261-3,198) untuk menderita hipertensi derajat 1 dibandingkan responden yang tidak obesitas. Setelah dilakukan analisis multivariat, terdapat 3 variabel kovariat yang diindentifikasi sebagai confounding yaitu variabel umur, riwayat hipertensi keluarga dan aktivitas fisik. Sehingga 
didapatkan besar hubungan obesitas dengan kejadian hipertensi derajat I yaitu sebesar 1,681 kali (CI 95\%: 1,049-2,696), artinya responden dengan obesitas memiliki risiko sebesar 1,681 kali untuk menderita hipertensi derajat 1 dibandingkan yang tidak obesitas setelah dikontrol variabel umur, riwayat hipertensi keluarga dan aktivitas fisik. Besar hubungan yang didapat dari penelitian ini hampir sama dengan penelitian sebelumnya. ${ }^{6,7}$ Tetapi lebih kecil bila dibandingkan beberapa penelitian lainnya. ${ }^{17,18}$

Hasil yang didapatkan dalam penelitian tersebut, kemungkinan masih dipengaruhi oleh adanya bias seleksi apabila dilihat dari aspek diantaranya proses pemilihan populasi penelitian, penggunaan desain cross sectional dan adanya missing data (data sekunder). Proses pengumpulan data dalam kegiatan Posbindu PTM dilakukan hanya pada responden yang datang dan bersedia untuk dilakukan pemeriksaan kesehatan, bisa dikatakan responden yang datang memiliki kepedulian terhadap kesehatannya, dikhawatirkan tidak mewakili populasi yang sebenarnya dalam penelitian.

Penggunaan desain cross sectional memiliki kelemahan, karena tidak adanya temporal time relationshipyang jelas, sehingga mengakibatkan aspek kausalitas menjadi kabur. Akan tetapi dalam penelitian ini menggunakan outcome hipertensi derajat 1 yang merupakan penyakit tahap dini, dapat diasumsikan bahwa penyakit baru dialami responden (belum pernah didiagnosis hipertensi sebelumnya atau dalam pengobatan hipertensi) dan belum adanya komplikasi organ, sehingga dapat diasumsikan bahwa penyebab (expose) kemungkinan besar mendahului akibat (outcome).

Sebanyak 30 orang responden (12\%) yang dilakukan pemeriksaan kesehatan, tidak bisa dianalisis karena data yang tidak lengkap (kadar GDS). Namun dilihat dari cakupan ketidaklengkapan data masih di bawah 20\% dan karakteristik umur terdapat kemiripin dengan sampel yang dianalisis yaitu sebagian besar berumur 41-50 tahun dan pemenuhan sampel minimal masih terpenuhi. Sehingga diharapkan tidak mempengaruhi hasil dari penelitian ini.

Selain dipengaruhi adanya bias seleksi, penelitian ini juga masih dipengaruhi adanya bias informasi. Sesuai rekomendasi WHO dan ISH, seseorang dinyatakan hipertensi, perlu dilakukan evaluasi ulang sekitar 1 atau 2 minggu. Selain itu alat ukur standar yang digunakan untuk mengukur tekanan darah adalah tensimeter air raksa. Akan tetapi dalam kegiatan Posbindu PTM ini hanya dinilai dalam satu waktu saja (baru dilaksanakan satu kali) dan menggunakan tensimeter digital, sehingga kemungkinan dapat mengakibatkan terjadinya bias pengukuran. Untuk meminimalisir bias pengukuran variabel hipertensi diantaranya dengan pengukuran tekanan darah dilakukan oleh tenaga medis terlatih dan penetapan diagnosis hipertensi dilakukan oleh dokter. Selain itu dilakukan kalibrasi rutin terhadap tensimeter digital tersebut (setahun sekali).

Pengukuran variabel riwayat hipertensi keluarga, konsumsi buah dan sayuran, dan aktifitas fisik sangat dipengaruhi oleh daya ingat responden, sehingga rentan terjadinya recall bias. Variabel kebiasaan merokok dan konsumsi alkohol sangat dipengaruhi oleh bias norma sosial sehingga dikhawatirkan hasil yang didapat tidak sesuai dengan kenyataan. Selain itu pengukuran variabel konsumsi buah dan sayuran serta aktifitas fisik tidak sesuai standar, hanya berdasarkan wawancara (kategori menggunakan standar Posbindu PTM) baik pada populasi terpajan maupun tidak terpajan, sehingga kemungkinan terjadinya misklasifikasi non-differentia/dan hasil yang didapatkan underestimate.

Apabila melihat nilai CI 95\%: 1,058-2,720, terlihat rapat atau cukup sempit. Ini memperlihatkan hasil penelitian yang diperoleh memiliki presisi yang baik. Selain itu berdasarkan perhitungan power of study dengan menggunakan rumus Lemeshow didapatkan hasil power of study yang kuat yaitu sebesar 99,9\%. Sehingga hasil penelitian kemungkinan bisa digeneralisasi di populasi target yaitu pegawai instansi Pemerintah dan BUMN di lingkungan Bandara Husein Sastranegara Bandung dan Pelabuhan Cirebon dan populasi yang mempunyai karakteritik yang sama dengan sampel penelitian ini.

\section{Simpulan dan Saran}

Berdasarkan hasil penelitian dan pembahasan yang telah diuraikan, adapun kesimpulan yang didapatkan adalah proporsi kejadian hipertensi derajat 1 di Posbindu PTM KKP Bandung tahun 2016 yaitu sebanyak 41,7\%. Sedangkan proporsi obesitas sebesar $54,9 \%$. Selain itu diketahui pula besar hubungan antara obesitas dengan kejadian hipertensi derajat 1 sebesar 1,681 (CI 95\%: 1,049-2,696), artinya responden dengan obesitas memiliki risiko sebesar 1,681 kali untuk menderita hipertensi derajat 1 dibandingkan yang tidak obesitas setelah dikontrol variabel umur, riwayat hipertensi keluarga dan aktivitas fisik.

Mengingat tingginya prevalensi hipertensi, maka perlunya mengoptimalkan kegiatan Posbindu PTM dengan rutin dilaksanakan sebulan sekali atau minimal setahun 2 kali (maksimal tiap pelaksanaan berjarak 1 bulan) sebagai salah satu upaya pencegahan dan pengendalian PTM khususnya hipertensi. Selain itu mengingat tingginya proporsi obesitas, berdasarkan hasil penelitian ini bila obesitas dapat dikendalikan, 59\% kasus hipertensi baru di wilayah kerja KKP Bandung dapat dicegah. Sehingga perlu peningkatan upaya promosi kesehatan meliputi ditambahkannya penyuluhan dan konseling gizi serta aktivitas olahraga bersama (senam) dalam kegiatan posbindu tersebut.

Selain itu saran untuk penelitian sejenis, perlu dilakukan perbaikan instrumen pengukuran (kuesioner). Karena kelemahan lain dalam penelitian ini adalah adanya beberapa faktor risiko yang tidak diukur dengan ukuran standar diantaranya konsumsi buah dan sayuran (sebaiknya diukur dengan food recall 24 jam) dan aktivitas fisik (contoh: standar WHO). Selain itu perlu ditambahkan pengukuran faktor risiko lain seperti konsumsi makanan asin, berlemak dan tingkat stres juga dianggap penting berkaitan dengan hipertensi. 


\section{Referensi}

1. World Health Organization. Global Status Report On Non Communicable Disease 2010. Jeneva; 2011

2. Kementerian Kesehatan RI. Riset Kesehatan Dasar 2013. Jakarta; 2014

3. Bustan, M. N. Epidemiologi Penyakit Tidak Menular, Rineka Cipta. Jakarta; 2007

4. Departemen Kesehatan RI. Pedoman Teknis Penemuan dan Tata Laksana Penyakit Hipertensi, Jakarta; 2006

5. Schmieder, R. E, Messerli FH. Does Obesity Influence Early Target Organ Damage in Hypertensive Patients?. American Heart Association 1993:87:1482-1488. [Internet]. 1993 [cited 2017 februari 9]. Available from: http://circ. ahajournals. org/content/87/5/1482

6. Jullaman. Hubungan Obesitas dengan Kejadian Hipertensi Stage 1 Pada Penduduk Usia Di atas 18 Tahun Yang berkunjung Ke Puskesmas di Wilayah Kabupaten Aceh Tamiang Tahun 2008. [Tesis]. Depok. Fakultas Kesehatan Masyarakat Universitas Indonesia; 2008

7. Sari, Dian M. Hubungan Obesitas Sentral dengan Kejadian Hipertensi Stage 1 di Posbindu PTM Kota Padang Tahun 2011. [Tesis]. Depok. Fakultas Kesehatan Masyarakat Universitas Indonesia; 2013

8. Kantor Kesehatan Pelabuhan Bandung. Laporan Kegiatan Skrining PTM. Bandung; 2015

9. Hidayat A. Metode Penelitian Kesehatan: Paradigma Kuantitatif. Surabaya: Health Books Publishing; 2011

10. Kementerian Kesehatan RI. Buku Pintar Posbindu PTM: Pengukuran Faktor Risiko PTM. Jakarta; 2015

11. Lee J, Chia KS. Estimation of prevalence rate ratios for cross sectional data: an example in occupational epidemiology. Br J Ind Med. 1993:50:861-862.

12. Haris, Syafruddin dan Taralan Tambunan. Hipertensi pada Sindrom Metabolik. Sari Pediatri (Vol.11 No.4). [Internet]. 2007 [cited 2017 april 9]. Available from:http:// www.saripediatri.idai.or.id/pdfile/11-4-6.pdf

13. Widyanto F. C dan Triwibowo C. Trend Disease "Trend Penyakit Saat Ini". TIM. Jakarta: 2013

14. Deborah, S.K \& Marion, R.W. Obesity and Hypertension. Drug Topics, 144(1), 59. [Internet]. 2000 [cited 2017 februari 9]. Available from: http://search.proquest.com/ docview/205086043? Accountid $=25074$

15. Juhaeri. Associations Between Weight Gain and Incident Hypertension in Bi-Ethnic Cohort: The Atherosclresosis Risk in Communities Study. International Journal of Obesity. 2002;58-64

16. Ridjab, Denio A. Modifikasi Gaya Hidup dan Tekanan Darah. Majalah Kedokteran Indonesia (Vol.57 No.13). [Internet]. 2007 [cited 2017 april 9]. Available from: http:/ $\angle m k i$. i d i o n I $n$ e. o r g/ index.php?upage =mki.mkidl\&smod $=$ mki=public\&key=MTEILTEO

17. Rahajeng, Ekowati dan Sulistyowati Tuminah. Prevalensi Hipertensi dan Determinanya di Indonesia. Majalah Kedokteran Indonesia (Vol.59 No.12). [Internet]. 2009 [cited 2017 februari 9]. Available from: http://indonesia. digitaljournals.org/index.php/idnmed/article/download/ $\underline{700 / 699}$

18. Pradono, Julianty. Faktor Determinan Terjadinya Hipertensi dan Implikasi pada Program Intervensi. [Disertasi]. Depok. Fakultas Kesehatan Masyarakat Universitas Indonesia; 2013. 